日植病報 $48: 471-481$ (1982)

Ann. Phytopath. Soc. Japan 48: 471-481 (1982)

\title{
Inductive Effect of Inosine on Formation of Secondary Appressoria from Conidia of Botrytis cinerea
}

\author{
Katsumi Akutsu*, Yumiko Kobayashi*, Tadakazu Watanabe**, \\ Keido Kō* and Tomomasa Misato* \\ 阿久津克已* ・ 小林裕美子*・渡部忠一**・黄 耿堂* ・見里朝正* : 灰色かび \\ 病菌の第 2 次付着器形成に対するイノシンの誘導作用について
}

\begin{abstract}
Purine-related compounds, cyclic AMP, 5'-AMP, 5'-IMP, adenosine and inosine, induced formation of secondary appressoria of Botrytis cinerea on slide glass in the presence of glucose. Among these purine-related compounds, formation of the secondary appressoria was remarkable in inosine. Formycin B, which is an analogue to inosine, reduced inductive effects of the secondary appressoria with inosine, and competed with inosine in forming the secondary appressoria. The administration of inosine to mycelia of $B$. cinerea resulted in an increase of syntheses of both DNA and RNA, followed by an increase of protein synthesis. When the mycelia incorporated ${ }^{14} \mathrm{C}$-inosine were fractionated, radioactivity was detected in RNA fraction at early time after incubation, and afterward in DNA fraction. Formycin B did not inhibit biosynthesis of cellular macromolecules in the mycelia, but inhibited DNA synthesis stimulated with inosine. It was shown that formycin B competed with inosine for DNA synthesis. These results indicated that inosine stimulated DNA synthesis, followed by an increase in RNA and protein syntheses in the mycelia, resulting in induction of the secondary appressoria.
\end{abstract}

(Received January 7, 1982)

Key Words: appressorial formation, Botrytis cinerea, inosine.

\section{Introduction}

The author et al. ${ }^{13)}$ reported that the purine-related compound solutions containing glucose stimulated the infection by conidia of Botrytis cinerea on cucumber leaves, and the stimulative effect was most remarkable in inosine solution among the solutions. The conidia formed secondary appressoria after elongation of superficial hyphae, and invasion by them was observed in the purine-related compound solutions containing glucose $^{1)}$. Also, it is suggested that glucose might be of use for the conidial germination, formation of the primary appressoria and elongation of the superficial hyphae, and that inosine might play a significant role in formation of the secondary appressoria ${ }^{1}$.

On the plant surface, several factors have been known to stimulate or inhibit the appressorium formation ${ }^{2,3,4,7,15,21,22)}$, so we attempted to determine whether or not the

* The Institute of Physical and Chemical Research, Wako, Saitama 351, Japan 理化学研究所

** Toho Chemical Ind. Co. Ltd. Technical Research Laboratory, Yokosuka, Kanagawa 237, Japan 東邦化学工業株式会社技術研究所

Present address of the first author: Faculty of Agriculture, Ibaraki University, Ami-machi, Ibaraki, 300-03, Japan 茨城大学農学部 
purine-related compounds induce formation of the secondary appressoria of $B$. cinerea on slide glass.

We investigated also on the biochemical effects of inosine on metabolism of cellular macromolecules, and effects of formycin B, an analogue compound of inosine, on formation of the secondary appressoria and metabolism of cellular macromolecules.

\section{Materials and Methods}

Fungus. Botrytis cinerea was subcultured on potato-dextrose agar at $20 \mathrm{C}$ in dark. The conidia were collected by the method described previously ${ }^{1)}$.

Plant. The seedlings of cucumber, cultivar Sagami Hanjiro, which was grown under the condition described previously were used ${ }^{1)}$. The primary leaves were cut into disks of $15 \mathrm{~mm}$ diameter with a cork borer and placed on moistened filter papers in sterile Petri dishes.

Chemicals. The purine-related compounds used in this study were cyclic adenosine $-5^{\prime}$-monophosphate (cyclic AMP), adenosine $-5^{\prime}$-monophosphate ( $5^{\prime}-\mathrm{AMP}$ ), inosine $-5^{\prime}$-monophosphate (5'-IMP), adenosine and inosine. Formycin $\mathrm{B}, 3-\left[\beta-\mathrm{D}^{-}\right.$ Ribofuranosyl]-pyrazolo-[4, 3-d] $6 \mathrm{H}-7$-pyrimidone, was obtained from P-L Biochemical Inc., 6-Benzyladenine-- $\mathrm{HCl}$ (Kyowa Hakkō Co.), kinetin (Wako Pure Chemical Co.) and $\mathrm{t}$-zeatin (Sigma Chemical Co.) were employed as cytokinins. All radioactive compounds labelled uniformly were purchased from the RCC in England.

Inoculation. Conidial suspension in the compound solution adjusted to $1 \times 10^{5}$ conidia/ml as inocula on cucumber leaf disks and that to $2 \times 10^{4}$ conidia/ml on slide glass were used. The concentration of each compound was adjusted to $1 \times 10^{-3} \mathrm{M}$, and these compound solutions containd $5 \%$ glucose. A $5 \mu \mathrm{l}$ droplet of each conidial suspension was placed on leaf disks or slide glass, and incubated at the condition described previously ${ }^{1)}$.

Light microscopical observation. The inoculated leaf disks were fixed in FAA (Formalin: Ethanol: Acetic acid=1:1:1) solution 12, 24 and $48 \mathrm{hr}$ after inoculation, stained with cotton blue solution, and observed under a light microscope. The conidia on slide glass were observed $3,6,12,24,48$ and $72 \mathrm{hr}$ after incubation using a Nomarski interference apparatus.

Mycelial preparation. The conidia $\left(1 \times 10^{6}\right.$ conidia/ml $)$ were grown in PS (potato-sucrose) medium with shaking at $20 \mathrm{C}$ for $18 \mathrm{hr}$. The cultured mycelia were washed with $0.01 \mathrm{M}$ Tris- $\mathrm{HCl}$ buffer $(\mathrm{pH} \mathrm{7.0)}$ and suspended in the Tris- $\mathrm{HCl}$ buffer containing $1 \%$ glucose for tracer experiments.

Incorporation of ${ }^{14}$ C-amino acid mixture into protein. The reaction mixture consisted of $4.5 \mathrm{ml}$ of mycelial suspension containing $1 \%$ glucose and $0.5 \mathrm{ml}$ of the aqueous solution of inosine or formycin $\mathrm{B}$ to make $1 \times 10^{-5}, 1 \times 10^{-4}$ and $1 \times 10^{-3} \mathrm{M}$ in final concentration. The mixture was preincubated for $1 \mathrm{hr}$ at $20 \mathrm{C}$ on a reciprocal shaker, and incubated with addition of $0.1 \mu \mathrm{Ci} / \mathrm{ml}$ of ${ }^{14} \mathrm{C}$-amino acid mixture $(57 \mathrm{mCi} /$ $\mathrm{mAtom})$. One $\mathrm{ml}$ of the reactioned mixtures at fixed time of incubation was withdrawn and the reaction was stopped by the addition of $1 \mathrm{ml}$ of $10 \%$ perchloric acid.

Mycelial proteins were fractionated by the method of Ogur and Rosen ${ }^{19)}$, and hydrolyzed overnight in $1 \mathrm{~N} \mathrm{NH}_{4} \mathrm{OH}$ at room temperature. The alkaline soluble protein 
was separated from the residue by centrifugation at $2700 \times g$ for $15 \mathrm{~min}$., and its content was determined by the method of Lowry ${ }^{16)}$. Radioactivity was measured by a liquid scintillation spectrophotometer (Packard TRI-CARB).

Incorporation of ${ }^{14} \boldsymbol{C}$-uridine and ${ }^{14} \boldsymbol{C}$-thymidine. The procedure of radioisotope incorporation into the mycelia was the same as above. One-tenth $\mu \mathrm{Ci} / \mathrm{ml}$ of ${ }^{14} \mathrm{C}$-uridine $(490 \mathrm{mCi} / \mathrm{mmole})$ and ${ }^{14} \mathrm{C}$-thymidine $(56.7 \mathrm{mCi} / \mathrm{mmole})$ in final radioactivity were used for incorporation to RNA and DNA, respectively. RNA and DNA in mycelia were fractionated by the method of Ogur and Rosen ${ }^{19}$, and the radioactivity of them was counted.

Incorporation of ${ }^{14}$-acetate. To determine the incorporation of ${ }^{14} \mathrm{C}$-acetate into lipid fraction, $0.1 \mu \mathrm{Ci} / \mathrm{ml}$ of ${ }^{14} \mathrm{C}$-acetate $(58 \mathrm{mCi} / \mathrm{mmole})$ was used in final radioactivity. The lipid fraction was prepared by the method of Bligh and Dyer ${ }^{5)}$ and the radioactivity of the lipid fraction was counted as cpm per total lipids.

Incorporation of ${ }^{14} \boldsymbol{C}$-glucosamine. Incorporation was performed by the same procedure as described above. The final radioactivity of ${ }^{14} \mathrm{C}$-glucosamine $(286 \mathrm{mCi}$ ) mmole) was $0.1 \mu \mathrm{Ci} / \mathrm{ml}$. The chitin fraction was prepared by the method of Blumenthal and $\operatorname{Roseman}^{6)}$ and the radioactivity incorporated into chitin was counted as the total $\mathrm{cpm}$ per $\mathrm{ml}$ of the sample.

Incorporation of ${ }^{14} \mathrm{C}$-inosine. To determine the incorporation of ${ }^{14} \mathrm{C}$-inosine into the mycelia, the reaction mixture consisting of $4.5 \mathrm{ml}$ of mycelial suspension containing $1 \%$ glucose and $0.5 \mathrm{ml}$ of the aqueous solution of inosine or formycin $\mathrm{B}$ to make $1 \times 10^{-4} \mathrm{M}$ in final concentration was prepared. The mixtures were incubated with addition of $0.2 \mu \mathrm{Ci} / \mathrm{ml}$ of ${ }^{14} \mathrm{C}$-inosine $(575 \mathrm{mCi} / \mathrm{mmole})$. One $\mathrm{ml}$ of the reaction mixtures at fixed time of incubation was withdrawn and the reaction was terminated by the addition of $1 \mathrm{ml}$ of $10 \%$ perchloric acid. The mycelia were fractionated by the method of Huang et al. ${ }^{11)}$ and the radioactivity of $1 \mathrm{ml}$ of each macromolecular fraction was counted.

\section{Results}

\section{Effects of purine-related compounds on the conidial growth of Botrytis cinerea on slide glass}

The percentages of conidial germination in each purine-related compound solution containing glucose and glucose solution were about $100 \% 12 \mathrm{hr}$ after incubation and higher than in distilled water (Table 1). The germinated conidia formed primary appressoria within about $12 \mathrm{hr}$ after incubation (Plate I-1). Nearly $100 \%$ of germinated conidia formed the primary appressoria in all solutions except control (Table 1). In glucose solution, hyphae elongated from the primary appressoria, and many hyphal branches were formed within $72 \mathrm{hr}$ after incubation on slide glass, but the formation of secondary appressoria was scarcely observed (Table 1, and Plates I-4 and 5). However, in purine-related compound solutions, the hyphae elongated from the primary appressoria and formed multicellular appressoria (secondary appressoria) within $72 \mathrm{hr}$ after incubation (Table 1, and Plates I-6 and 7). Among the purine-related compound solutions, formation of the secondary appressoria was remarkable in inosine solution (Table 1). 
Table 1. Germination and formation of primary and secondary appressoria from conidia of Botrytis cinerea in the solutions of purine-related compounds on slide glass ${ }^{a}$

\begin{tabular}{lccc}
\hline \hline \multicolumn{1}{c}{ Compounds ${ }^{\mathrm{b})}$} & $\begin{array}{c}\text { Germination } \\
(\%)^{\mathrm{c})}\end{array}$ & $\begin{array}{c}\text { Formation of primary } \\
\text { appressoria }(\%)^{\mathrm{d})}\end{array}$ & $\begin{array}{c}\text { Formation of secondary } \\
\text { appressoria }{ }^{\mathrm{e})}\end{array}$ \\
\hline Cyclic AMP & 97.3 & 98.6 & 13 \\
$5^{\prime}$-AMP & 98.4 & 95.2 & 18 \\
$5^{\prime}$-IMP & 96.3 & 96.1 & 23 \\
Adenosine & 97.8 & 97.4 & 27 \\
Inosine & 98.0 & 96.5 & 31 \\
Glucose & 95.0 & 95.7 & 2 \\
Control (distilled water) & 53.4 & 53.1 & 0 \\
\hline
\end{tabular}

a) The mean of three trials. Conidia on slide glass were incubated at $20 \mathrm{C}$ under $12 \mathrm{hr}$-illumination of fluorescent light per day and observed $48 \mathrm{hr}$ after incubation.

b) $1 \times 10^{-3} \mathrm{M}$ purine-related compound solutions containing $5 \%$ glucose

c) Percentage of germinated conidia to total conidia

d) Percentage of primary appressorium-forming conidia to germinated conidia

e) Numbers of secondary appressoria per $1 \times 10^{2}$ conidia

\section{Competitive relation between inosine and formycin $B$ to formatiom of secondary appressoria and lesion}

In $1 \times 10^{-3} \mathrm{M}$ formycin $\mathrm{B}$ containing only glucose, the conidia formed small lesions on cucumber leaf disks $48 \mathrm{hr}$ after inoculation (Table 2). The germinated conidia formed primary appressoria and elongated superficial hyphae, but no secondary appressoria were formed. Aggressive lesions were formed by application of inosine into conidial suspension on the leaf disks in the presence of formycin B. In these aggressive lesions, the secondary appressoria were formed and the numbers increased in proportion to the increase of inosine concentration.

On slide glass, formation of the secondary appressoria in $5 \mu \mathrm{l}$ droplet was increased

Table 2. Competitive relation between inosine and formycin $\mathrm{B}$ to formation of secondary appressoria and lesions by conidia of Botrytis cinerea on cucumber leaves ${ }^{\text {a) }}$

\begin{tabular}{|c|c|c|c|c|c|}
\hline \multicolumn{4}{|c|}{ Composition of conidial suspension } & \multirow{2}{*}{$\begin{array}{l}\text { Formation of secondary } \\
\left.\text { appressoria }{ }^{b}\right)\end{array}$} & \multirow{2}{*}{$\begin{array}{l}\text { Diameter of } \\
\text { lesions }(\mathrm{mm})^{\mathrm{c})}\end{array}$} \\
\hline $\begin{array}{l}\text { Concentrations } \\
\text { of inosine }(\mathrm{M})\end{array}$ & $5 \%$ & glucose & $\begin{array}{l}1 \times 10^{-3} \mathrm{M} \\
\text { formycin } \mathrm{B}\end{array}$ & & \\
\hline 0 & & + & + & 0 & 5 \\
\hline $1 \times 10^{-6}$ & & + & + & 5 & 11 \\
\hline $1 \times 10^{-5}$ & & + & + & 11 & 13 \\
\hline $1 \times 10^{-4}$ & & + & + & 19 & 15 \\
\hline $1 \times 10^{-3}$ & & + & + & 25 & 13 \\
\hline $1 \times 10^{-3}$ & & + & - & 41 & 15 \\
\hline 0 & & + & - & 0 & 0 \\
\hline
\end{tabular}

\footnotetext{
a) The mean of three trials

b) Numbers of secondary appressoria per lesion were counted $48 \mathrm{hr}$ after inoculation.

c) Diameters were measured $48 \mathrm{hr}$ after inoculation.
} 
Table 3. Competitive relation between inosine and formycin B to formation of secondary appressoria from germinated conidia of Botrytis cinerea on slide glass $^{\text {a) }}$

\begin{tabular}{|c|c|c|c|}
\hline \multicolumn{2}{|c|}{ Composition of conidial suspension } & \multicolumn{2}{|c|}{ Formation of secondary appressoria ${ }^{b}$} \\
\hline \multirow{2}{*}{$\begin{array}{l}\text { Concentrations } \\
\text { of inosine (M) }\end{array}$} & \multirow{2}{*}{$5 \%$ glucose } & \multicolumn{2}{|c|}{ Concentrations of formycin B (M) } \\
\hline & & $1 \times 10^{-4}$ & $1 \times 10^{-5}$ \\
\hline 0 & + & 4 & 6 \\
\hline $1 \times 10^{-6}$ & + & 9 & 16 \\
\hline $1 \times 10^{-5}$ & + & 14 & 18 \\
\hline $1 \times 10^{-4}$ & + & 20 & 28 \\
\hline $1 \times 10^{-3}$ & + & 24 & 37 \\
\hline $1 \times 10^{-4}$ & + & & lout formycin B) \\
\hline 0 & + & & lout formycin B) \\
\hline
\end{tabular}

a) The mean of three trials

b) Numbers of secondary appressoria per $1 \times 10^{2}$ conidia were counted $72 \mathrm{hr}$ after incubation.

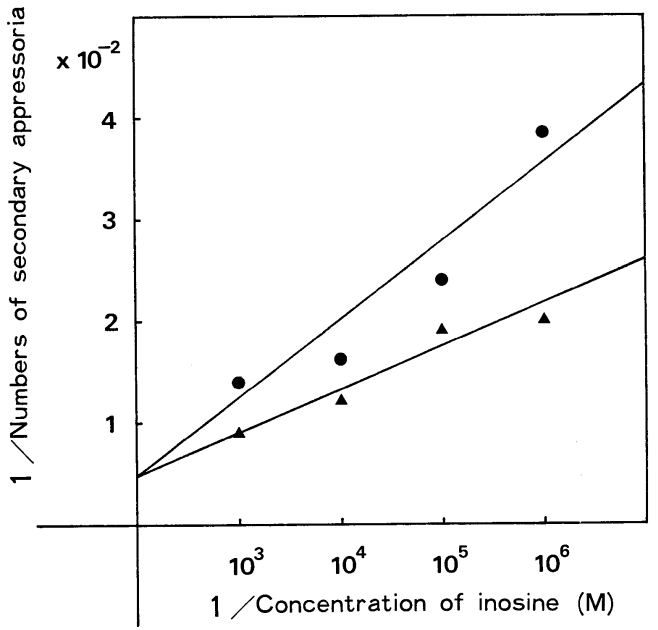

Fig. 1. Lineweaver-Burk plots obtained from relation between inosine and formycin $B$ to the secondary appressorium formation from germinated conidia of Botrytis cinerea, $\mathbf{\Delta}, 1 \times 10^{-5} \mathrm{M}$ formycin $\mathrm{B}$;, $1 \times 10^{-4} \mathrm{M}$ formycin $\mathrm{B}$. with the increase of inosine concentration containing $1 \times 10^{-5}$ and $1 \times 10^{-4} \mathrm{M}$ formycin B (Table 3). The Lineweaver-Burk plots obtained from relation between inosine and formycin B to the secondary appressorium formation showed that formycin $B$ competed with inosine in forming the secondary appressoria (Fig. 1).

\section{Effects of cytokinins on formation} of the secondary appressoria

In all cytokinin solutions containing glucose, the formation of secondary appressoria and lesions was not observed on cucumber leaf disks.

\section{Effects of inosine and formycin $B$ on mycelial metabolism}

The effects of inosine and formycin $B$ on the incorporation of various labelled precursors into the macromolecules of mycelial cells were studied (Table 4).

When the mycelial suspension containing $1 \%$ glucose was incubated with ${ }^{14} \mathrm{C}$-acetate in the presence of inosine or formycin $B$ for $1 \mathrm{hr}$, there was no remarkable difference in incorporation of ${ }^{14} \mathrm{C}$-acetate into the mycelial lipid fraction.

By using ${ }^{14} \mathrm{C}$-glucosamine, the effects of inosine and formycin $\mathrm{B}$ on incorporation into chitin of mycelial cell wall was also shown in Table 4 . Inosine and formycin B did not show any effects on the incorporation of ${ }^{14} \mathrm{C}$-glucosamine.

Formycin B did not show remarkable effects on the incorporation of ${ }^{14} \mathrm{C}-$ amino acid mixture into alkaline soluble and insoluble protein fractions. In the presence of inosine, 
Table 4. Effects of inosine and formycin B on the mycelial metabolism of Botrytis cinerea

\begin{tabular}{|c|c|c|c|c|c|c|c|}
\hline \multirow{2}{*}{ Compounds " } & \multirow{2}{*}{$\begin{array}{l}\text { Incubation } \\
\text { times (hr) }\end{array}$} & \multicolumn{6}{|c|}{ Incorporation of the dosed ${ }^{14} \mathrm{C}$-precursors $(\mathrm{cpm})^{\mathrm{a})}$} \\
\hline & & Lipid & Chitin & $\begin{array}{l}\text { Alkaline soluble } \\
\text { protein }\end{array}$ & $\begin{array}{l}\text { Alkaline insoluble } \\
\text { protein }\end{array}$ & RNA & DNA \\
\hline & 0 & 1009 & 68 & 450 & 1563 & 97 & 75 \\
\hline Inosine & 1 & 11942 & 1517 & 10076 & 23400 & 4188 & 625 \\
\hline \multirow[t]{2}{*}{$\left(1 \times 10^{-4} \mathrm{M}\right)$} & 3 & 13586 & 5020 & 9356 & 19367 & 4519 & 1361 \\
\hline & 5 & 12749 & 11150 & 14263 & 32556 & 3352 & 1071 \\
\hline \multirow{4}{*}{$\begin{array}{l}\text { Formycin B } \\
\left(1 \times 10^{-4} \mathrm{M}\right)\end{array}$} & 0 & 748 & 59 & 883 & 1154 & 116 & 58 \\
\hline & 1 & 13854 & 1382 & 17900 & 26443 & 2009 & 437 \\
\hline & 3 & 13072 & 4722 & 18338 & 27940 & 3117 & 712 \\
\hline & 5 & 11985 & 11500 & 10563 & 21003 & 2754 & 759 \\
\hline \multirow{4}{*}{$\begin{array}{l}\text { Control } \\
(1 \% \text { glucose) }\end{array}$} & 0 & 783 & 62 & 368 & 651 & 92 & 71 \\
\hline & 1 & 10213 & 1275 & 19273 & 28572 & 1826 & 427 \\
\hline & 3 & 12594 & 5603 & 20087 & 31037 & 2099 & 732 \\
\hline & 5 & 11370 & 13029 & 13972 & 23950 & 1894 & 678 \\
\hline
\end{tabular}

a) The mean of three trials. ${ }^{14} \mathrm{C}$-Acetate, ${ }^{14} \mathrm{C}$-glucosamine, ${ }^{14} \mathrm{C}$-amino acid mixture, ${ }^{14} \mathrm{C}$-uridine and ${ }^{14} \mathrm{C}$-thymidine were used as precursors of lipid, chitin, protein, RNA and DNA, respectively.

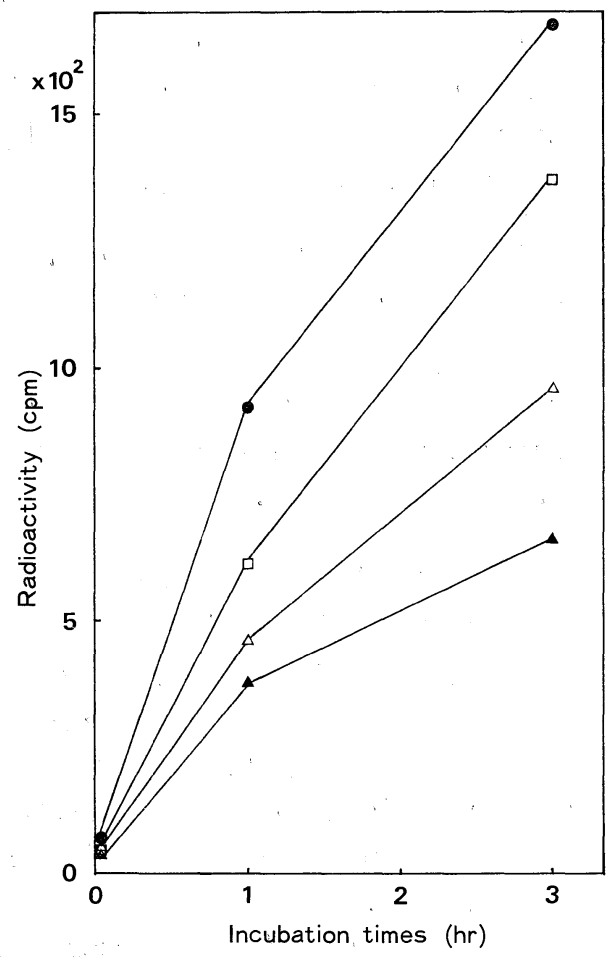

Fig. 2. Effects of inosine on the incorporation of ${ }^{14} \mathrm{C}$-thymidine into DNA fraction of mycelia of Botrytis cinerea. $\triangle, 1$ $\times 10^{-5} \mathrm{M} ; \square, 1 \times 10^{-4} \mathrm{M} ; \bigcirc, 1 \times 10^{-3}$ $\mathrm{M} ; \mathbf{\Delta}$, control. the incorporation of ${ }^{14} \mathrm{C}$-amino acid mixture into protein fractions decreased at $3 \mathrm{hr}$ after incubation tempoarily, but increased at $5 \mathrm{hr}$ after incubation.

On the incorporation of ${ }^{14} \mathrm{C}$-uridine into RNA fraction of the mycelia; inosine showed remarkably stimulative effect, and formycin B showed somewhat higher than that of control in the incorporation of ${ }^{14} \mathrm{C}-$ uridine into RNA fraction.

When the mycelial suspension was incubated with ${ }^{14} \mathrm{C}$-thymidine, inosine stimulated the incorporation of ${ }^{14} \mathrm{C}$-thymidine into DNA fraction, but formycin B did not show any effect. The incorporation of ${ }^{14} \mathrm{C}$-thymidine into the DNA fraction of mycelia increased with the increase of inosine concentration (Fig. 2).

Competitive relation between inosine and formycin $B$ to the incorporation of ${ }^{14} \mathrm{C}$-thymidine into $\mathrm{DNA}$ fraction of mycelia

From the above experiments, it was found that inosine and formycin B showed 


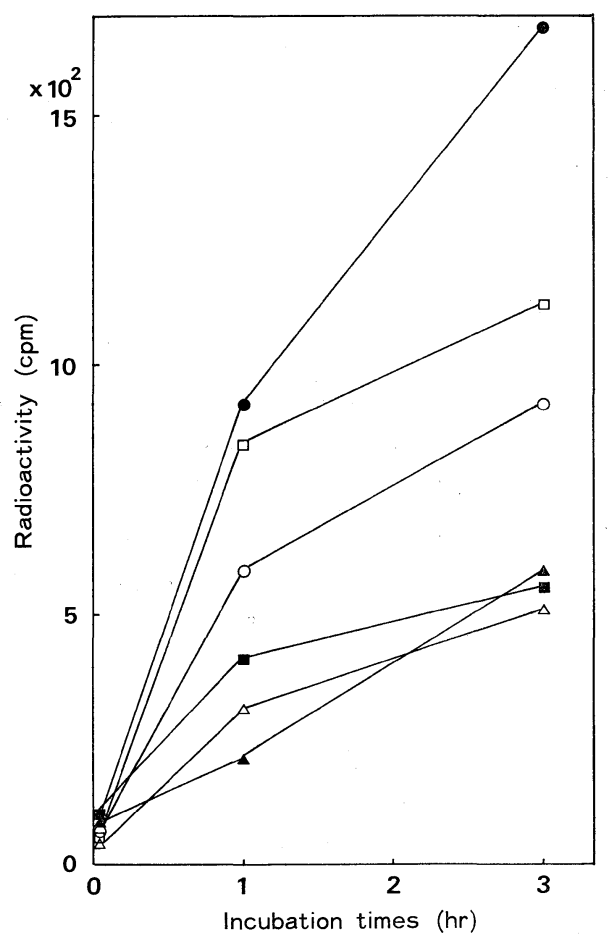

Fig. 3. Competitive relation between inosine and formycin $\mathrm{B}$ to the incorporation of ${ }^{14} \mathrm{C}$-thymidine into DNA fraction of mycelia of Botrytis cinerea.

$1 \times 10^{-3} \mathrm{M}$ inosine; $\square, 1 \times 10^{-3} \mathrm{M}$ inosine $+1 \times 10^{-3} \mathrm{M}$ formycin $\mathrm{B}$; $\bigcirc, 1 \times 10^{-4} \mathrm{M}$ inosine $+1 \times 10^{-3} \mathrm{M}$ formycin $\mathrm{B}$; $1 \times 10^{-5} \mathrm{M}$ inosine + $1 \times 10^{-3} \mathrm{M}$ formycin $\mathrm{B} ; \triangle, 1 \times 10^{-3}$ $\mathrm{M}$ formycin $\mathrm{B} ; \boldsymbol{\Delta}$, control.

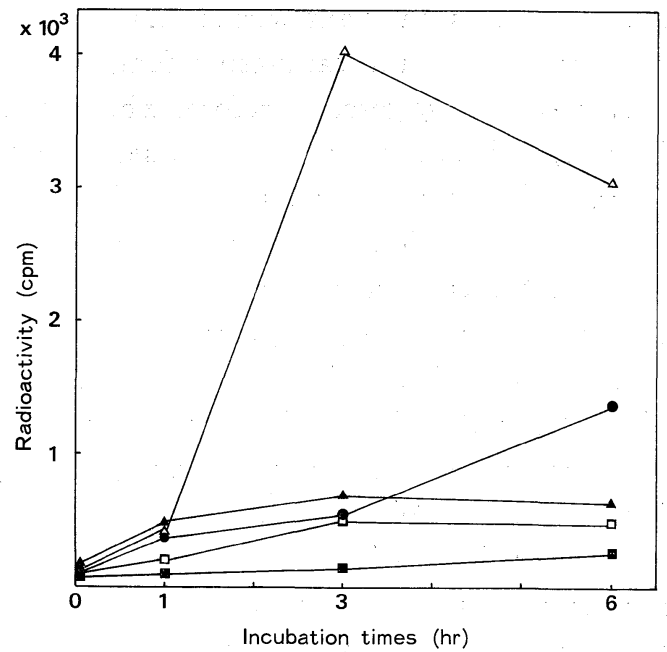

Fig. 4. Incorporation of ${ }^{14} \mathrm{C}$-inosine into some macromolecular fractions from mycelia of Botrytis cinerea. D, Lipid fraction; $\square$, Alkaline soluble protein fraction; $\mathbf{\Delta}$, Alkaline insoluble protein fraction; $\triangle$, RNA fraction; DNA fraction.

competitive relation to formation of the secondary appressoria (Tables 2 and 3 , Fig: 1). Also, the experiment on the incorporation of labelled compounds showed that inosine stimulated the incorporation of ${ }^{14} \mathrm{C}-$ thymidine into DNA fraction, but no effect of formycin B in its incorporation (Table 4). Accordingly, relation between inosine and formycin $\mathrm{B}$ to the incorporation of

${ }^{14} \mathrm{C}$-thymidine into DNA fraction was examined.

By $1 \times 10^{-3} \mathrm{M}$ formycin $\mathrm{B}$, the incorporation of ${ }^{14} \mathrm{C}$-thymidine into the DNA fraction increased in proportion to the increase of inosine concentration (Fig. 3).

\section{Incorporation of ${ }^{14}$ C-inosine into macromolecule fractions of mycelial cells}

Mycelia incubated in the presence of ${ }^{14} \mathrm{C}$-inosine were prepared to examine which macromolecule fraction does incorporate inosine. The higher radioactivity was detected in RNA fraction $3 \mathrm{hr}$ after incubation, and in DNA fraction $6 \mathrm{hr}$ after incubation (Fig. 4).

\section{Discussion}

It was reported that in infection process by conidia of Botrytis cinerea on cucumber leaves, glucose stimulated conidial germination, formation of primary appressoria and elongation of superficial hyphae, and that inosine induced formation of secondary appressoria ${ }^{1)}$. These findings were obtained in vivo by using cucumber leaves, and 
several factors on plant surface have been known to stimulate or inhibit formation of appressoria of plant pathogenic fungi ${ }^{2,3,4,7,15,17,21,22)}$. To compare the case on cucumber leaves we investigate, therefore, whether or not the purine-related compounds, especially inosine, induce formation of the secondary appressoria in conidia of $B$. cinerea on slide glass. The present results indicated that the purine-related compounds had an inductive effect on formation of the secondary appressoria in the presence of glucose, and that the effect was most remarkable in inosine. These results support that inosine induces to form the secondary appressoria in $B$. cinerea.

From the biochemical examination, the administration of inosine to mycelia of $B$. cinerea resulted in an increase of syntheses of both DNA and RNA, followed by an increase of protein synthesis (Table 4). Furthermore, when the mycelia which incorporated ${ }^{14} \mathrm{C}-$ inosine were fractionated, radioactivity was detected in RNA fraction $3 \mathrm{hr}$ after incubation, and in DNA fraction $6 \mathrm{hr}$ after incubation (Fig. 4). These results suggest that inosine may play a role as trigger of DNA synthesis rather than as precursor of DNA synthesis in mycelia of $B$. cinerea. Formycin B did not inhibit biosyntheses of the cellular macromolecules in mycelia of $B$. cinerea, but inhibited the DNA synthesis stimulated with inosine (Table 4 and Fig 3). It was shown that formycin B competed with inosine for formation of the secondary appressoria and the DNA synthesis (Figs. 1 and 3). These results indicated that inosine stimulated de novo DNA synthesis, followed by an increase of RNA and protein syntheses in the mycelia, resulting in induction of the secondary appressoria.

It has been reported that cyclic AMP plays an important role as an intracellular inducer in morphogenesis, for example, formation of fruiting bodies in the higher Basidiomycetes $^{8,18,20)}$ and formation of conidia $^{14,23,24)}$, zoosporangia $^{26,27)}$ and sclerotia ${ }^{97}$ in the plant pathogenic fungi. Cyclic AMP induced formation of the secondary appressoria in $B$. cinerea, but the inductive effect of cyclic AMP was lower than inosine, $5^{\prime}$-AMP, 5'-IMP and adenosine ${ }^{1}$. $5^{\prime}$-AMP, 5'-ADP and $5^{\prime}$-ATP were not effective in inducing fruiting bodies ${ }^{12)}$, sclerotia ${ }^{9)}$ and zoosporangia ${ }^{26)}$, but these nucleotides were effective in inducing the secondary appressoria ${ }^{1)}$. These facts suggest that the morphogenesis of the secondary appressoria as infection structure formed in only pathogenic fungi is different from that of fruiting bodies, sclerotia and zoosporangia. Also, 5'-ATP and cyclic AMP were immediately transformed into 5'-AMP and inosine in cell free system of $B$. cinerea mycelia ${ }^{13}$. It has been known that cyclic AMP incorporated into animal cells is converted to AMP, ADP, ATP and inosine ${ }^{10)}$. Uno and Ishikawa ${ }^{25)}$ indicated that incorporated cyclic AMP might have been immediately converted by the action of phosphodiesterase to 5'-AMP. From these facts, the purine-related compounds, which are effective in forming the secondary appressoria, may be postulated to act through inosine in the stage of induction of the secondary appressoria of $B$. cinerea.

Some cytokinins, which take part in morphogenesis of higher plants, showed no inductive effect in formation of the secondary appressoria. However, it is interesting that inosine is common to cytokinins in the chemical structure. 


\section{Literature cited}

1. Akutsu, K., Kobayashi, Y., Matsuzawa, Y., Watanabe, T., Kō, K. and Misato, T. (1981). Ann. Phytopath. Soc. Japan 47 : 234-243.

2. Blakeman, J. P. (1971). In Ecology of Leaf Surface Micro-Organisms (Preece, T. F. and Dickinson, C. H. eds.). Academic Press, London and New York. p. 255-268.

3. Blakeman, J. P. and Atkinson, P. (1976). In Microbiology of Aerial Plant Surface (Dickinson, C. H. and Preece, T. F. eds.). Academic Press, London and New York. p. 441-450.

4. Blakeman, J. P. and Brodie, I. D. S. (1976). In Microbiology of Aerial Plant Surface (Dickinson, C. H. and Preece, T. F. eds.). Academic Press, London and New York. p. 529-558.

5. Bligh, E. G. and Dyer, W. J. (1959). Can. J. Biochem. Physiol. 37 : 911-917.

6. Blumenthal, H. J. and Rosenman, S. (1957). J. Bacteriol. 74 : 222-224.

7. Dickinson, S. (1970). Phytopath. Z. 69: 115-124.

8. Gold, M. H. and Cheng, T. M. (1979). Arch. Microbiol. $121: 37-41$.

9. Hashiba, T. and Ishikawa, T. (1978). Phytopathology 68: 1723-1727.

10. Heidrick, M. L. and Ryan, W. L. (1971). Biochim. Biophys. Acta. 237 : 301-309.

11. Huang, K. T., Misato, T. and Asuyama, H. (1964). J. Antibiotics Ser. A. $17: 65-70$.

12. Ishikawa, T. and Uno, I. (1980). Fermentation and Industry 38: 327-335 (in Japanese).

13. Kō, K., Akutsu, K., Kobayashi, Y., Om, Y., Watanabe, T. and Misato, T. (1981). Ann. Phytopath. Soc. Japan 47 : 228-233.

14. Larsen, A. D. and Sypherd, P. S. (1974). J. Bacteriol. $117: 432-438$.

15. Lenne, J. M. and Parbery, D. G. (1976). Trans. Br. mycol. Soc. $66: 334-336$.

16. Lowry, O. H., Rosenbrough, N. J., Farr, A. L. and Randall, R. J. (1951). J. Biol. Chem. 193: 265-275.

17. Maheshwari, R., Allen, P. J. and Hildebrandt, A.C. (1967). Phytopathology $57: 855-862$.

18. Matthews, T. R. and Niderpruem, D. J. (1972). Arch. Microbiol. 87 : 257-268.

19. Ogur, M. and Rosen, G. (1950). Arch. Biochem. Biophys. 25 : 262-276.

20. Oyama, Y., Yoshida, T. and Taguchi, H. (1974). Mushroom Science IX (part 1) : 719-731.

21. Parbery, D. G. and Blakeman, J. P. (1978). Trans. Br. mycol. Soc. 70: 7-19.

22. Swinburne, T. R. (1976). Phytopath. Z. $87: 74-90$.

23. Turian, G. and Khandjian, E. (1973). Bull. Soc. Bot. Suisse 83: 352-357.

24. Tsuboi, M. and Yanagishima, N. (1973). Arch. Microbiol. 93: 1-12.

25. Uno, I. and Ishikawa, T. (1973). J. Bacteriol. 113: 1240-1248.

26. Yoshikawa, M. (1979). Shokubutsu Bōeki 33: 452-455 (in Japanese).

27. Yoshikawa, M. and Masago, H. (1977). Can. J. Bot. 55: 840-843.

\section{和 文 摘 要}

\section{灰色かび病菌の第 2 次付着器形成に対するイノシンの誘導作用について \\ 阿久津克己 - 小林裕美子 - 渡部忠一・黄 耿堂 - 見里朝正}

灰色かび病菌の第 2 次付着器形成に対する核酸塩基プリン関連化合物 (cyclic AMP, $5^{\prime}$-AMP 5'-IMP, adenosine, inosine) の誘導効果をスライドグラス上で検討した。これらの物質はキュウリ葉上の場合と同様 に第 2 次付着器形成を誘導するが，中でもイノシンが最も顕著な効果を示した。化学構造上イノシンの類似 物質であるホルマイシンBをイノシン溶液に添加すると, 第 2 次付着器形成の誘導効果が抑えられ, 両者間

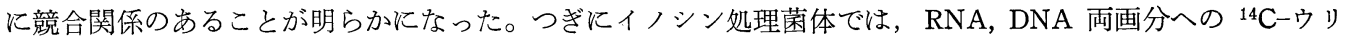

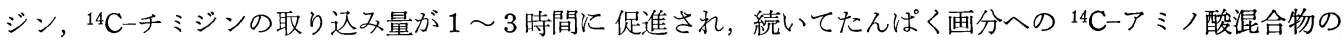
取り込みが促進された。一方，ホルマイシンBは DNA 画分への ${ }^{14} \mathrm{C}-$ チミジンの取り込みに対して，イノシ ンと競合することを示したが，他の画分では競合関係はみられなかった。以上のことから，イノシンによる 第 2 次付着器形成誘導には, DNA 合成が関与し, その DNA に基づく RNA, たんぱく合成など一連の生合 成系が関与すると考えられる。 


\section{Explanation of Plate}

Plate I. Light micrographs of the growth process in conidia of Botrytis cinerea in the presence of inosine on slide glass

1. Growth process in conidia of $B$. cinerea in the presence of inosine solution containing glucose on slide glass, $12 \mathrm{hr}$ after incubation

2. Growth process in conidia of $B$. cinerea in the presence of distilled water on slide glass, 48 hr after incubation

3. High magnification of 2

4. Hyphae elongated from primary appressoria in the presence of glucose on slide glass, $48 \mathrm{hr}$ after incubation

5. High magnification of 4

6. Secondary appressoria formed in the presence of inosine solution containing glucose on slide glass, $48 \mathrm{hr}$ after incubation

7. High magnification of 6

All scales : $10 \mu \mathrm{m}$

\section{Abbreviation}

c, conidium; gt, germ tube; h, hypha: pa, primary appressorium; s, septum ; sa, secondary appressorium. 


\section{Plate I}
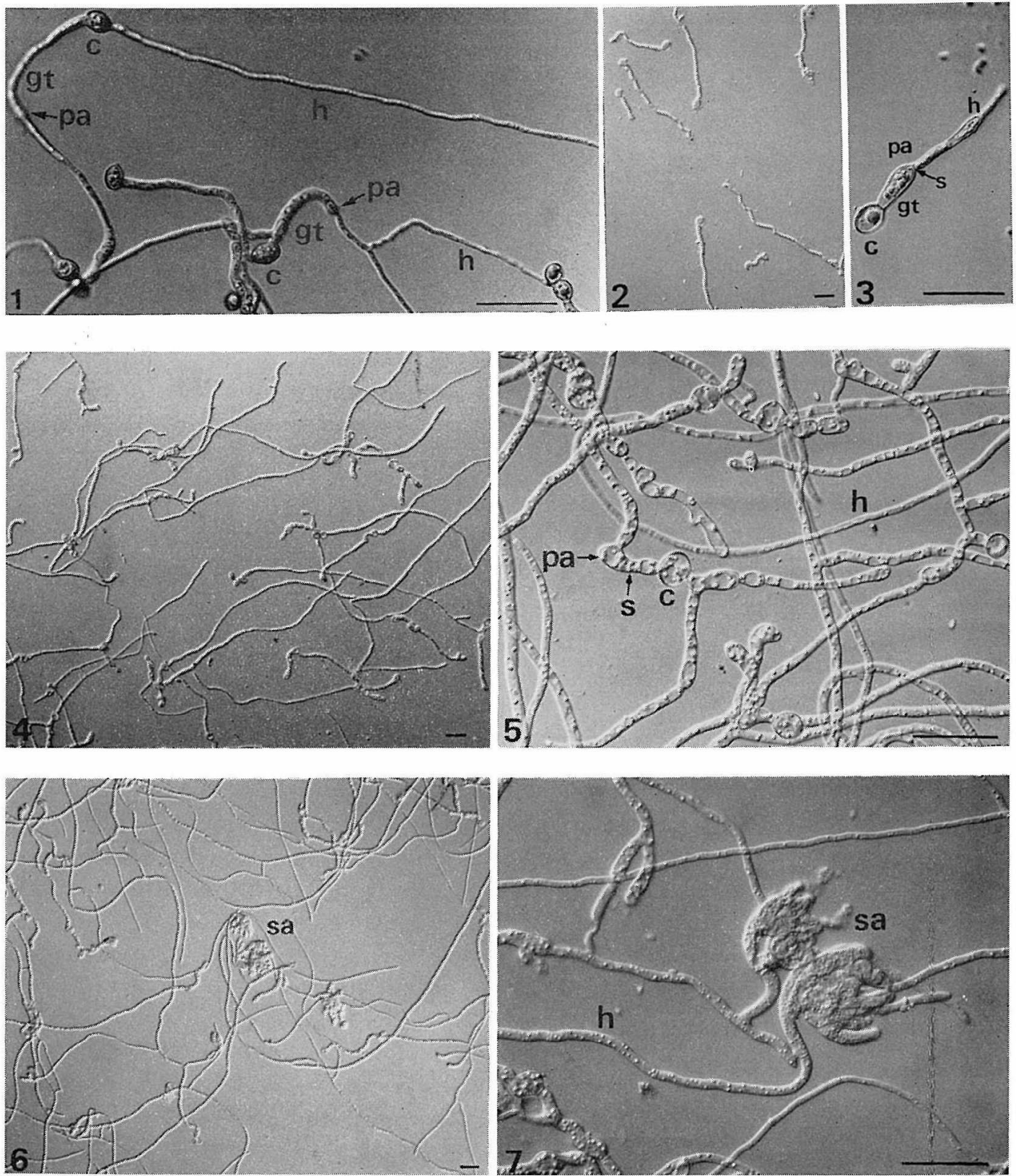